\title{
Heparin effect in alveolar cells and macrophages in an acute lung injury model
}

\author{
M Camprubí-Rimblas ${ }^{1 *}$, R Guillamat-Prats ${ }^{2}$, T Lebouvier $^{3}$, L Chimenti ${ }^{1}$ M Iglesias ${ }^{4}$, C Obiols ${ }^{4}$, J Tijero ${ }^{1}$, MN Gómez ${ }^{1}$, \\ C de Haro ${ }^{5}, \mathrm{~L}$ Blanch $^{1,2}$, A Artigas $^{2,5}$ \\ From ESICM LIVES 2015 \\ Berlin, Germany. 3-7 October 2015
}

\section{Introduction}

Acute Lung Injury (ALI) and Acute Respiratory Distress Syndrome (ARDS) are characterized by a promptly release of proinflammatory mediators that downregulate natural anticoagulant mechanisms, initiate the coagulation system, impair fibrinolysis and produce the rupture of the endothelial and epithelial monolayer [1]. Inflammation of ALI/ARDS is initiated and strongly regulated by proinflammatory activation of macrophages, which lead to the recruitment of other inflammatory cells, producing alveolar cells injury, propagating the coagulant response and promoting the injury. Currently there is no effective treatment for this disease. Previous studies have presented the beneficial effect of anticoagulants, not only for their anticoagulation activity but also for their antiinflammatory action [2],[3].

\section{Objectives}

To evaluate the effect of the treatment with heparin in human alveolar cells and alveolar macrophages after induce an injury, mimicking an in-vitro ALI.

\section{Methods}

Human alveolar primary cells and alveolar macrophages from pulmonary biopsies were isolated and seeded. Sodium non-fractioned heparin $(100 \mathrm{UI} / \mathrm{ml})$ was administered to the cells after the induction of an injury with a pro-inflammatory stimulus (Cytomix: mix of TNF $\alpha$, IL1 $\beta$ and IFN $\gamma ; 25 \mathrm{ng} / \mathrm{ml}$ or Lipopolysaccharide protein from Escherichia coli 055 : B5; $1000 \mathrm{ng} / \mathrm{ml}$ ). The effect of heparin was assessed by the analysis of proinflammatory markers (IL12p40, iNOS, TNF $\alpha$ and IL-1 $\beta$ ) and antiinflammatory markers (IL10 and IL13), cell proliferation

${ }^{1}$ Fundación Parc Taulí, Sabadell, Spain

Full list of author information is available at the end of the article and permeability (measuring transmembrane resistance). Data are expressed as mean \pm SEM (units are relative to the expression of control group). Statistical analysis was performed using One-Way-ANOVA and post-hoc (Newman Keuls) test. Statistical significance $\mathrm{p} \leq 0.05$ is considered.

\section{Results}

Heparin was able to modify the inflammatory response of both cell populations, decreasing it significantly $(\mathrm{p} \leq 0.05)$ in the case of macrophages (iNOS: Control: $1 \pm 0.09$, Injured group:41.68 \pm 4.86 , Heparin group:0.54 \pm 0.06 . IL12p40: Control: $1 \pm 0.11$, Injured group:46.74 \pm 4.32 , Heparin group:0.15 \pm 0.009 ). The permeability of the monolayer and cell proliferation of alveolar cells did not show changes.

\section{Conclusions}

Heparin has an immunomodulatory effect in alveolar cells and reduces inflammation in macrophages. This mechanism produced by heparin could have a beneficial effect in ALI.

\section{Grant Acknowledgment}

PI12/02548, Fundació Parc Taulí and CIBERES

\section{Authors' details}

${ }^{1}$ Fundación Parc Taulí, Sabadell, Spain. ${ }^{2}$ Ciber de Enfermedades Respiratorias, Sabadell, Spain. ${ }^{3}$ Ponchaillou University Hospital, Surgical Intensive Care, Rennes, France. ${ }^{4}$ University Hospital of Mutua de Terrassa, University of Barcelona, Thoracic Surgery Service, Terrassa, Spain. ${ }^{5}$ Corporación Sanitaria y Universitaria Parc Taulí, Critical Care Center, Sabadell, Spain.

\section{Published: 1 October 2015}

\section{References}

1. Ware LB, Matthay MA: The acute respiratory distress syndrome. $N$ Engl J Med 2000, 342:1334-1349.

\section{SpringerOpen $^{\circ}$}

(c) 2015 Camprubí-Rimblas et al.; This is an Open Access article distributed under the terms of the Creative Commons Attribution License (http://creativecommons.org/licenses/by/4.0), which permits unrestricted use, distribution, and reproduction in any medium, provided the original work is properly cited. 
2. Mu E, Ding R, An X, Li X, Chen X, Ma X: Heparin attenuates lipopolysaccharide-induced acute lung injry by inhitibiting nitric oxide synthase and TGF- $\beta /$ Smad signaling pathway. Thromb Res 2012, 129(4):479-485.

3. Li Y, Sun JF, Cui X, Mani H, Danner RL, Li X, et al: The effect of heparin administration in animal models of sepsis: A prospective study in Escherichia coli-challenged mice and a systematic review and metaregression analysis of published studies. Crit Care Med 2011, 39(5):1104-1112

doi:10.1186/2197-425X-3-S1-A570

Cite this article as: Camprubí-Rimblas et al:: Heparin effect in alveolar cells and macrophages in an acute lung injury model. Intensive Care Medicine Experimental 2015 3(Suppl 1):A570.

\section{Submit your manuscript to a SpringerOpen ${ }^{\mathcal{O}}$ journal and benefit from:}

- Convenient online submission

- Rigorous peer review

- Immediate publication on acceptance

- Open access: articles freely available online

- High visibility within the field

- Retaining the copyright to your article

Submit your next manuscript at $\gg$ springeropen.com 